\title{
MICROBIOLOGICAL ASSESSMENT OF INDOOR AIR OF TEACHING HOSPITAL WARDS: A CASE OF JIMMA UNIVERSITY SPECIALIZED HOSPITAL
}

\author{
Samuel Fekadu ${ }^{1}$, Bahilu Getachewu ${ }^{1}$
}

\begin{abstract}
BACKGROUND: Hospital environment represents a congenial situation where microorganisms and susceptible patients are indoors together. Thus, the objective of this study is to provide fundamental data related to the microbial quality of indoor air of Jimma University Specialized Hospital wards, to estimate the health hazard and to create standards for indoor air quality control.

METHODS: The microbial quality of indoor air of seven wards of Jimma University Specialized Hospital was determined. Passive air sampling technique, using open Petri-dishes containing different culture media, was employed to collect sample twice daily.

RESULTS: The concentrations of bacteria and fungi aerosols in the indoor environment of the wards ranged between $2123-9733 \mathrm{CFU} / \mathrm{m}^{3}$. The statistical analysis showed that the concentrations of bacteria that were measured in all studied wards were significantly different from each other (p-value=0.017), whereas the concentrations of fungi that were measured in all sampled wards were not significantly different from each other ( $p$-value=0.850). Moreover, the concentrations of bacteria that were measured at different sampling time (morning and afternoon) were significantly different ( $p$-value $=0.001$ ).

CONCLUSION: All wards that were included in the study were heavily contaminated with bacteria and fungi. Thus, immediate interventions are needed to control those environmental factors which favor the growth and multiplication of microbes, and it is vital to control visitors and students in and out the wards. Moreover, it is advisable that strict measures be put in place to check the increasing microbial load in the hospital environment.

KEYWORDS: Indoor air, Microbiological assessment, Sedimentation technique, Open-plate technique, Hospital environment, Bacteria, Fungi
\end{abstract}

DOI: http://dx.doi.org/10.4314/ejhs.v25i2.3

\section{INTRODUCTION}

Air pollution, both indoor and outdoor, is one of the most severe roblems of our time. Several airborne diseases have been related to the indoor air quality $(1,2)$. Indoor air quality is a significant issue in healthcare. Healthcare facilities have to pay particular care and attention to indoor air concerns due to the presence of air borne microorganism that may cause nosocomial infection $(3,4,5,6,7)$. People with pre-existing health problems who are going through treatment and those who may have depressed immune systems are very susceptible to indoor air exposures. The Center for Disease Control and Prevention of U.S. estimates that more than two million patients acquire infections per year in U.S. hospitals, while they are hospitalized for other health problems, and that 88,000 die as a direct or indirect result (8). The hospital environment thus represents a congenial situation where microorganisms and susceptible patients are together indoors. As stated by Riley "the enclosed atmosphere of a hospital building and its human

\footnotetext{
${ }^{1}$ Department of Environmental Health Science and Technology, College of Public Health and Medical Science, Jimma University, Ethiopia

Corresponding Author: Samuel Fekadu, Email: samuel.fekadu@ju.edu.et/sami.fekadu@yahoo.com
} 
occupants constitute an ecological unit" (9). For this reason, hospital environmental control procedures can be an effective support in reducing nosocomial infections $(10,11)$.

The healthcare facilities, especially in developing countries, are complex settings where factors such as overcrowding, improper design and poor ventilation can impact on the growth and survival of microorganism which is harmful to human health. A study done on the interaction of building designs and microbial load showed that, there are high microbial loads for those buildings which did not include vents, proper situation of windows and doors, as well as low head-roof (15). Moreover, the activity of people and equipment within the indoor environments is thought to be the principal factor contributing to the buildup and spread of airborne microbial contaminations (4, $12,15,16)$.

Therefore, this study was designed to see the extent of indoor air microbial contamination in the maternity, surgical and medical wards of Jimma University Specialized Hospital. The findings of this study are helpful to evaluate the adequacy of environmental control procedures of ward environments.

\section{MATERIALS AND METHODS}

The study was conducted from February to June, 2013 in Jimma University Specialized Hospital (JUSH). Jimma University Specialized Hospital is the only teaching and referral hospital in the southwestern part of Ethiopia. It has a bed capacity of 450 and a total of more than 750 staffs of both supportive and professional. It provides services for approximately 9000 inpatient and 80000 outpatient attendances a year coming from the catchment population of about 15,000 million people. Seven wards were used for sample collection and these included two maternity wards, three surgical wards and two medical wards.

Bacteria and fungi measurement were made by passive air sampling technique: the settle plate method using $9 \mathrm{~cm}$ diameter Petri dishes (63.585 $\mathrm{cm}^{2}$ areas) (17). The sampling height which approximated the human breathing zone was $1 \mathrm{~m}$ above the floor and at the center of the room. Bacteria and fungi were collected on $2 \%$ nutrient agar and 4\% sabouroad agar respectively. To avoid self-contamination of agar plate during air sampling, sterile gloves, mouth masks and protective gown were worn, and before it was used the agar plate was checked visually for any microbial growth.

To obtain the appropriate surface density for counting and to determine the load with respect to time of exposure, the sampling times were set at 30, 60, 90 minutes. Moreover, samples were collected twice a day at 8:30am and 4:00pm by taking into consideration the variation of density of occupant and environmental factors.

After exposure, the sample were taken to the laboratory (Department of Environmental Health Science and Technology, Jimma University) and incubated at $37^{\circ}$ for 24 hours for bacteria and at $25^{\circ}$ for 3 days for fungi.

Once colony forming units (CFU) were enumerated, colony forming units per cubic meter $\left(\mathrm{CFU} / \mathrm{m}^{3}\right)$ were determined, taking into account the following equation described by Omeliansky $(18,19)$ :

Where

$$
\mathrm{N}=5 \mathrm{a} \cdot 10^{4}(\mathrm{bt})^{-1}
$$

$\mathrm{N}$ : microbial $\mathrm{CFU} / \mathrm{m}^{3}$ of indoor air;

a: number of colonies per Petri dish;

b: dish surface, $\mathrm{cm}^{2}$;

t: exposure time, minutes.

SPSS Statistics version 16.0 software was applied to determine the likelihood of statistically significant differences between the concentrations of bacteria and fungi measured at different sampling places and the linearity was determined between the concentrations of bacteria and fungi measured.

\section{RESULTS}

The indoor air microbial loads of seven wards of Jimma University Teaching Hospital were determined by taking 84 samples. The results of the research into the concentration, concentration range, arithmetic mean and standard deviation of bacteria and fungi aerosol present in the investigated wards are presented in Tables 1, 2 and 3. And the microbial air quality standard of the wards is indicated in Table 4.

The results indicate that the highest bacterial colony forming unit per $\mathrm{m}^{3}$ air was recorded at 4:00 pm in Maternity W01 ward at 90 minutes exposure. This was $9733 \mathrm{CFU} / \mathrm{m}^{3}$. While the lowest bacterial colony forming unit per $\mathrm{m}^{3}$ air was recorded at 8:30am in Surgical W02 ward at 
60 minutes exposure. This was $3106 \mathrm{CFU} / \mathrm{m}^{3}$ (Tables 1 and 3).

The highest fungi colony forming unit per $\mathrm{m}^{3}$ air was recorded at 4:00pm in Medical W02 ward at 90 minutes exposure $\left(4168 \mathrm{CFU} / \mathrm{m}^{3}\right)$ and the lowest fungi colony forming unit per $\mathrm{m}^{3}$ air was recorded at 4:00pm in Medical W01 ward at 30 minutes exposure $\left(2123 \mathrm{CFU} / \mathrm{m}^{3}\right)$ as can be seen on Tables 2 and 3.

Table 1: Number of bacterial colony counts (CFU) per $\mathrm{m}^{3}$ air at different sampling time of day at different time of exposure

\begin{tabular}{|l|l|l|l|l|l|l|}
\hline \multirow{4}{*}{} & \multicolumn{5}{|c|}{ Sampling time } \\
\cline { 2 - 7 } & \multicolumn{4}{|c|}{$8: 30 \mathrm{am}$} & \multicolumn{3}{c|}{$4: 00 \mathrm{pm}$} \\
\cline { 2 - 7 } & \multicolumn{2}{|c|}{ Petri dish exposure time (Minutes) } & \multicolumn{1}{c|}{ Petri dish exposure time (Minutes) } \\
\cline { 2 - 7 } Sampling sites & $\mathbf{3 0}$ (Min.) & $\mathbf{6 0}$ (Min.) & $\mathbf{9 0}$ (Min.) & $\mathbf{3 0}$ (Min.) & $\mathbf{6 0}$ (Min.) & $\mathbf{9 0}$ (Min.) \\
\hline Maternity W01 & 3355 & 3290 & 3425 & 8309 & 8807 & 9733 \\
\hline Maternity W02 & 3145 & 3211 & 3355 & 8466 & 8702 & 8021 \\
\hline Surgical W01 & 3643 & 3159 & 5090 & 3198 & 4390 & 6029 \\
\hline Surgical W02 & 3329 & 3106 & 4893 & 3381 & 4272 & 6002 \\
\hline Surgical W03 & 3408 & 4351 & 4954 & 3565 & 4548 & 6291 \\
\hline Medical W01 & 5426 & 6881 & 7514 & 6920 & 7824 & 7968 \\
\hline Medical W02 & 5688 & 6802 & 7444 & 7234 & 7483 & 7898 \\
\hline
\end{tabular}

Table 2: Number of fungi colony counts $(\mathrm{CFU})$ per $\mathrm{m}^{3}$ air at different sampling time of day at different time of exposure

\begin{tabular}{|l|l|l|l|l|l|l|}
\hline \multirow{2}{*}{} & \multicolumn{5}{|c|}{ Sampling time } \\
\cline { 2 - 7 } & \multicolumn{3}{|c|}{ 8:30am } & \multicolumn{3}{c|}{$4: 00 \mathrm{pm}$} \\
\cline { 2 - 7 } Sampling sites & Petri dish exposure time (Minutes) & \multicolumn{1}{c|}{ Petri dish exposure time (Minutes) } \\
\cline { 2 - 7 } (Min.) & $\mathbf{6 0}$ (Min.) & $\mathbf{9 0}$ (Min.) & $\mathbf{3 0}$ (Min.) & $\mathbf{6 0}$ (Min.) & $\mathbf{9 0}$ (Min.) \\
\hline Maternity W01 & 2228 & 2477 & 2787 & 3565 & 3696 & 4106 \\
\hline Maternity W02 & 2280 & 2346 & 2665 & 3355 & 3539 & 4072 \\
\hline Surgical W01 & 2254 & 2660 & 3311 & 2674 & 3041 & 3049 \\
\hline Surgical W02 & 2411 & 2700 & 3268 & 2569 & 3001 & 3067 \\
\hline Surgical W03 & 2883 & 2778 & 3408 & 3014 & 2923 & 3006 \\
\hline Medical W01 & 2909 & 2844 & 3477 & 2123 & 2975 & 4010 \\
\hline Medical W02 & 2752 & 2923 & 3408 & 2490 & 3159 & 4168 \\
\hline
\end{tabular}

Table 3: The range of microbe's distribution at Jimma University Specialized Hospital wards

\begin{tabular}{|l|r|r|r|r|r|}
\hline & \multicolumn{1}{|c|}{$\mathrm{N}$} & \multicolumn{1}{c|}{ Minimum } & \multicolumn{1}{|c|}{ Maximum } & \multicolumn{1}{|c|}{ Mean } & \multicolumn{1}{|c|}{ Std. Deviation } \\
\hline Bacteria CFU/m3 & 42 & 3106 & 9733 & 5583 & 2053 \\
Fungi CFU/m3 & 42 & 2123 & 4168 & 3008 & 525 \\
Valid N (list wise) & 42 & & & & \\
\hline
\end{tabular}


Table 4: An assessment of air quality in the selected wards of Jimma University Specialized Hospital according to the sanitary standards for non-industrial premises

\begin{tabular}{|c|c|c|c|c|c|c|c|c|c|c|c|c|c|c|c|c|}
\hline \multirow{3}{*}{$\begin{array}{l}\text { Group of } \\
\text { microbes }\end{array}$} & \multirow{3}{*}{$\begin{array}{l}\text { Range of values } \\
\left(\mathrm{CFU} / \mathrm{m}^{3}\right)\end{array}$} & \multirow{3}{*}{$\begin{array}{l}\text { Pollution } \\
\text { degree }\end{array}$} & \multicolumn{14}{|c|}{ Sampling Sites and time } \\
\hline & & & \multicolumn{2}{|c|}{ Maternity W01 } & \multicolumn{2}{|c|}{ Maternity W02 } & \multicolumn{2}{|c|}{ Surgical W01 } & \multicolumn{2}{|c|}{ Surgical W02 } & \multicolumn{2}{|c|}{ Surgical W03 } & \multicolumn{2}{|c|}{ Medical W01 } & \multicolumn{2}{|c|}{ Medical W02 } \\
\hline & & & $\begin{array}{l}8: 30 \\
\text { am }\end{array}$ & $4 \mathrm{pm}$ & $\begin{array}{l}8: 30 \\
\text { am }\end{array}$ & $4 \mathrm{pm}$ & $\begin{array}{l}8: 30 \\
\text { am }\end{array}$ & $4 \mathrm{pm}$ & $\begin{array}{l}8: 30 \\
\mathrm{am}\end{array}$ & $4 \mathrm{pm}$ & $\begin{array}{l}8: 30 \\
\text { am }\end{array}$ & $4 \mathrm{pm}$ & $\begin{array}{l}8: 30 \\
\text { am }\end{array}$ & $4 \mathrm{pm}$ & $\begin{array}{l}8: 30 \\
\text { am }\end{array}$ & $\begin{array}{l}4 \\
\mathrm{pm}\end{array}$ \\
\hline \multirow[t]{5}{*}{ Bacteria } & $<50$ & Very Low & & & & & & & & & & & & & & \\
\hline & $50-100$ & Low & & & & & & & & & & & & & & \\
\hline & $100-500$ & Intermediate & & & & & & & & & & & & & & \\
\hline & $500-2000$ & High & & & & & & & & & & & & & & \\
\hline & $>2000$ & Very high & $\checkmark$ & $\checkmark$ & $\checkmark$ & $\checkmark$ & $\checkmark$ & $\checkmark$ & $\checkmark$ & $\checkmark$ & $\checkmark$ & $\checkmark$ & $\checkmark$ & $\checkmark$ & $\checkmark$ & $\checkmark$ \\
\hline & & & & & & & & & & & & & & & & \\
\hline \multirow[t]{5}{*}{ Fungi } & $<25$ & Very Low & & & & & & & & & & & & & & \\
\hline & $25-100$ & Low & & & & & & & & & & & & & & \\
\hline & $100-500$ & Intermediate & & & & & & & & & & & & & & \\
\hline & $500-2000$ & High & & & & & & & & & & & & & & \\
\hline & $>2000$ & Very high & $\checkmark$ & $\checkmark$ & $\checkmark$ & $\checkmark$ & $\checkmark$ & $\checkmark$ & $\checkmark$ & $\checkmark$ & $\checkmark$ & $\checkmark$ & $\checkmark$ & $\checkmark$ & $\checkmark$ & $\checkmark$ \\
\hline
\end{tabular}

The scatter plots of bacteria versus fungi concentration that have been measured in all sampled wards, shows strong positive linear associations ( $p$ value $=0.001)$ with regression coefficient $\left(\mathrm{R}^{2}=0.52, \mathrm{n}=42\right)$ as presented in figure 1.

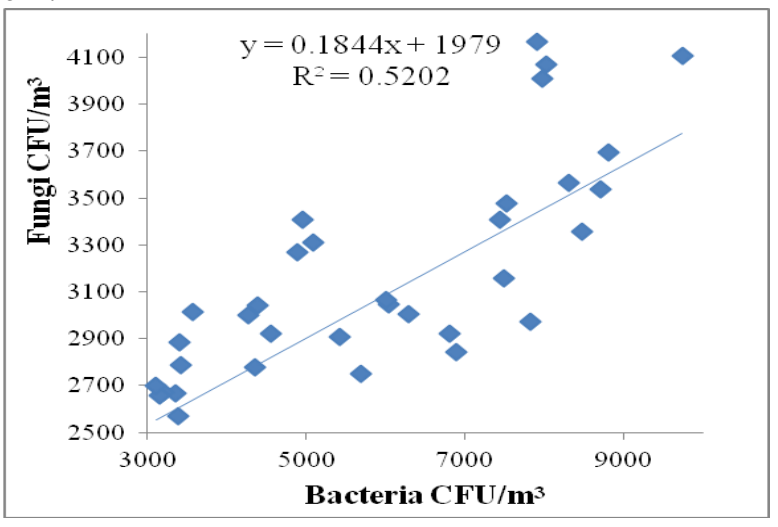

Figure 1: Correlation between fungi and bacteria concentration at Jimma University Specialized Hospital wards

\section{DISCUSSION}

Hospital related infections have been linked with many factors among which are the microbial qualities of the indoor air of different wards of each hospital (20). The concentrations of bacteria and fungi aerosols in the indoor environment of Jimma University Specialized Hospital wards, estimated with the use of the settle plate method, ranged between $2123-9733 \mathrm{CFU} / \mathrm{m}^{3}$.

There is no uniform international standard available on levels and acceptable maximum bioaerosol loads (21). Different countries have different standards. The work conducted by a WHO expert group on assessment of health risks of biological agents in indoor environments suggested that total microbial load should not exceed $1000 \mathrm{CFU} / \mathrm{m}^{3}$. If higher than this, the environment is considered as contaminated (22). Other authors consider that $300 \mathrm{CFU} / \mathrm{m}^{3}$ and $750 \mathrm{CFU} / \mathrm{m}^{3}$ should be the limit for fungi and bacteria respectively $(23,24)$. 
The quantitative interpretation of the results describing the air quality in the wards of JUSH was evaluated based on the sanitary standards for non-industrial premises formulated by the European Commission in 1993 (25). According to this classification, all wards that were included in the study were not in hygienic conditions (Table 4). These might be because of the number of individuals in the wards. At the time of this study, all wards were at their maximum capacity, as of visitors in and out the wards, the high density of patients and the presence of high number of health science students in the wards. Thereby increasing the shading of bacteria and agitation of air as it was indicated in previous studies $(26,27,28)$. Beside these, the environmental factors, mainly insufficient ventilation system might also contribute to the high microbial loads of the wards as indicated in the study done by Wamedo et al. 2012 (15). Moreover, as indicated in the result part, the scatter plots of the bacteria concentration versus fungi concentration show strong positive linear associations ( $p$-value $=0.001$ ). These prove that, the indoor air environmental factors of the wards are favoring the growth and development of bacteria and fungi population.

The statistical analysis showed that the concentrations of bacteria that were measured in all wards were significantly different from each other $\quad(p$-value $=0.017)$. Moreover, the concentrations of bacteria that were measured at different sampling time (morning and afternoon) were also significantly different $(p$-value $=0.001$ ). These can be mainly explained by the variation of density of occupants during sampling time as well as the variation of environmental factors $(15,29)$. Whereas the concentrations of fungi that were measured in all sampled wards were not significantly different to each other ( $p$ value $=0.850$ ), suggesting that most fungi species present into the air were not human-borne. Similar observations by others are in agreement with these data $(30,31,32)$.

In Conclusion, all wards that were included in the study were heavily contaminated with bacteria and fungi. The high bacteria and fungi concentrations of air obtained in this study might be potential risk factors for spread of nosocomial infection in JUSH. Thus, immediate interventions is needed to control those environmental factors which favor the growth and multiplication of microbes, and the Hospital needs to increase the number of wards to make them sufficient for the inpatients that come from catchment area. It is also vital to control visitors and students in and out of the wards. Moreover, it is advisable that strict measures be put in place to check the increasing microbial load in the hospital environment.

Additionally, it is necessary to adopt the guidelines for the design and construction of new health-care facilities and for renovation of existing facilities in order to control indoor air-quality. Experiences can be taken from the American Institute of Architects (AIA) that published excellent guidelines. These AIA guidelines address indoor air-quality standards (e.g., ventilation rates, temperature levels, humidity levels, pressure relationships, and minimum air changes per hour $[\mathrm{ACH}]$ ) specific to each zone or area in health-care facilities (e.g., operating rooms, laboratories, diagnostic areas, patient-care areas, and support departments) (33).

\section{ACKNOWLEDGEMENTS}

The authors are grateful to the Department of Environmental Health Science and Technology for providing lab facilities and to Jimma University Specialized Hospital staffs for providing access to the sampling points.

\section{REFERENCES}

1. Wasserman S. Basic mechanisms in asthma. Ann Allergy 1988; 16: 477-482.

2. Menzies D, Bourbeau J. Building-related illnesses. N Engl J Med, 1997; 337: 1524-1531.

3. Beggs CB. The Airborne Transmission of infection in hospital buildings, fact or Fiction? Indoor built Environ, 2003; 12: 9-18.

4. Ekhaise FO, Ighosewe OU, Arakpovi OD. Hospital indoor air borne micro flora in private and government owned Hospital in Benin City, Nigeria. World J of med sci, 2008; 3: 19-23.

5. Gammage RB, Kaye SV. Indoor and health. Chelsea MI. Lewis Publisher London, 1985: 215218.

6. Weiss KD, Osborne SF, Callahan-Lyon P. Prevention of surgical-site infections. $N$ Engl $J$ Med 2010; 362:1541-1542.

7. Barrow C. A patient's journey through the operating department from an infection control perspective. J Perioper Pract, 2009; 19: 94-98. 
8. Riley D, Freihaut J, Bahnfleth W.P, Karapatyan Z. Indoor Air Quality Management and Infection Control in Health Care Facility Construction. IAQ T3S1 Innovative techniques in IAQ 2004. Available

at:www.engr.psu.edu/iec/publications/papers/indoo r_air_quality.pdf

9. Riley R.L. The ecology of indoor atmosphere airborne infection in hospital. J of Chronic disease, 1972; 25: 421-423.

10. Demir F. A survey on prevention of surgical infections in operating theaters. Worldviews Evid Based Nurs 2009; 6:102-113.

11. Beldi G, Bisch-Knaden S, Banz V, Mühlemann K, Candinas D. Impact of intraoperative behavior on surgical site infections. Am J Surg, 2009; 198:157162.

12. Stezenbach LD. Introduction to Aerobiology manual of Environmental microbiology. $2^{\text {nd }}$ edition. Washington DC ASM press, 2002:801-813.

13. Stetzenbach LD, Buttner MP, Cruz P. Detection and enumeration of airborne contaminants. Curr Biotechnol 2004; 15:170-4.

14. Basharia AA Yousef, Ahmed AD Elshareef, Mubaruk AK Ibraheem, Samer S Alsayed. Assessment of indoor air quality in medical facilities in Sudan. Int $J$ of Sci and tech, 2013; 2: 92-95.

15. Wamedo SA, Ede $\mathrm{PN}$, Chuku A. Interaction between building design and air borne microbial load. Asian J of Bio Sci, 2012; 5:183-191.

16. Jaffal AA, Banat IM, El Mogheth AA, Nsanze H, Benar A, Ameen AS. Residential indoor airborne microbial populations in the United Arab Emirates. Envir Int, 1997; 23: 529-533.

17. Pasquarella C, Pitzurra O, Savino A. The index of microbial air contamination (review). J Hosp Infect, 2000; 46: 241-56.

18. Borrego S, Guiamet $\mathrm{P}, \mathrm{G}^{\prime}$ omez de Saravia $\mathrm{S}$ et al. "The quality of air at archives and the biodeterioration of photographs. Int Biodet and Biodeg, 2010; 64: 139-145.

19. Gutarowska B. Metabolic activity of moulds as a factor of building materials Biodegradation. Polish J of Micr, 2010; 59: 119-124.

20. Ekhaise FO, Isitor EE, Idehen O, Emogbene OA. Airborne micro flora in the atmosphere of an hospital environment of University of Benin Teaching Hospital (UBTH), Benin City, Nigeria. World J Agric Sci, 2010; 6: 166-170.

21. Jyotshna M, Helmut B. Bioaerosols in Indoor Environment - A Review with Special Reference to Residential and Occupational Locations. The Open Envir \& Biol Mon J, 2011; 4: 83-96.
22. Nevalainen A, Morawaska L. Biological Agents in Indoor Environments. Assessment of Health Risks. Work conducted by a WHO Expert Group between 2000-2003. WHO, QUT: 2009.

23. Francisco RAN, Luiz FGS. Guidelines for indoor air quality in offices in Brazil. Proceedings of Healthy Buildings, 2000; 4: 549-554.

24. Cappitelli F, Fermo P, Vecchi R, Piazzalunga A, Valli G, Zanardini E, et al. Chemical-physical and microbiological measurements for indoor air quality assessment at the ca' granda historical archive, Milan (Italy). Water Air Soil Pollut, 2009; 201: 109-120.

25. European Communities Commission. Indoor air quality and its impact on man. Report No. 12, Biological Particles in Indoor Environments. Luxembourg; 1993.

26. Hospodsky D, Qian J, Nazaroff WW, Yamamoto N, Bibby K, Rismani-Yazdi H, Peccia J. Human occupancy as a source of indoor airborne bacteria. PLoS ONE, 2012; 7: e34867.

27. Qian J, Hospodsky D, Yamamoto N, Nazaroff WW, Peccia J. Size-resolved emission rates of airborne bacteria and fungi in an occupied classroom. Indoor Air, 2012; 22: 339-351.

28. Meadow JF, Altrichter AE, Kembel SW, Kline J, Mhuireach G, Moriyama M, Northcutt D, O'Connor TK, Womack AM, Brown GZ, Green JL, Bohannan BJM. Indoor airborne bacterial communities are influenced by ventilation, occupancy, and outdoor air source. Indoor Air 2013; 24:41-48.

29. Graudenz GS, Oliveira CH, Tribess A, Mendes JC, Latorre M, Kalil J. Association of Air Conditioning with Respiratory Symptoms in Office Workers in Tropical Climate. Indoor Air, 2005; 15: 62-66.

30. Soto T, García Murcia RM, Franco A, VicenteSoler J, Cansado J, Gacto M. Indoor airborne microbial load in a Spanish university (University of Murcia, Spain). Anales de Biologia, 2009; 31: 109-115.

31. Soto T, Lozano M, Vicente-Soler J, Cansado J, Gacto M. Microbiological survey of the aerial contamination in urban areas of the city of Murcia, Spain. Anales de Biologia, 2009; 31:7-14.

32. Ingold CT. Fungal spores: their liberation and dispersal. Oxford University Press, UK: 1971.

33. American Institute of Architects. Guidelines for design and construction of hospital and health care facilities, 2001. Washington, DC: American Institute of Architects Press; 2001. Availableat:www.fgiguidelines.org/pdfs/2001guide lines.pdf 